\title{
Social Doctrine of Tourism: Cultural and Educational Aspects
}

\author{
Fedoryshyna Larysa, Felenchak Yuliia, Nyanko Vitaliy
}

\begin{abstract}
The theoretical approaches to the study of social doctrine, in particular the social doctrine of tourism is considered in the article. The social features of tourism development in modern conditions are reviewed. The basic approaches to understanding of social tourism as a separate type of tourism and its influence on social development are analyzed. The social content of the tourist service is considered as signs of social stratification.

The content of the concept of social doctrine of tourism is defined. The necessity of development and realization of effective social doctrine of tourism with the consideration of regional social specifics is substantiated. The scheme of the functional structure of the social doctrine of tourism is developed. The features of culture and education as the key components of the social doctrine of tourism are determined. The expediency of improving the quality of vocational education in tourism has been substantiated in connection with the intensification of social processes and raising the level of social and economic development.
\end{abstract}

Keywords : Social doctrine. Social stratification. Society. Tourism. Tourist service.

\section{INTRODUCTION}

In modern conditions, tourism is an integral part of the life of a dynamically developing society and according to experts (Dusenko 2011; Aparina 2015, et al.), accounts for one third of world trade in services. In the social aspect, tourism is an effective means of meeting the needs of people in rest, a unique indicator of the standard of living of the population, which, besides the positive influence on the social and economic development of the regions, promotes popularization of active rest, knowledge and preservation of cultural and historical heritage, development of tolerance, multiculturalism, stabilization of interethnic and interethnic relations, etc.

From such positions the formation and implementation of social doctrine in tourism is of great importance for raising the level of social and economic development of any country.

Revised Manuscript Received on November 15, 2019

* Correspondence Author

Fedoryshyna Larysa,Dr. Sc. (Econ.), Assoc. Prof.,Senior Research Fellow at the Department of Researches of Customs Risks,Scientific and Research Center of Customs Affair of Research Institute of Fiscal Policy of University of State Fiscal Service of Ukraine,Khmelnytskyi, Ukraine,email: larisa.fedorishina@gmail.com,

Felenchak Yuliia,Cand. Sc. (Econ.),Assistant Professor at the Department of sports tourism,Lviv State University of Physical Culture named after Ivan Boberskyi,Lviv, Ukraine, e-mail: yufelenchak@yahoo.com,

Nyanko Vitaliy,Cand. Sc. (Econ.), Assoc. Prof.,Assistant Professor at the Department of Marketing and Commercial Business, Khmelnitsky National University,Khmelnytskyi, Ukraine, e-mail: nvmmarket@gmail.com
The development and implementation of an effective social doctrine of tourism can solve the problems of resource dependence of regions, thereby eliminating regional disparities in economic and social development and contribute to the development of tourism as a powerful alternative industry with virtually inexhaustible resources for development.

The issue of social tourism was actively investigated in the works of many scholars (Asypova 2014; Badin 2008; Hryshkin 2001; Husliakova 2012; Zybarieva 2014; Serdobolska 2003; Shevchuk 2015; et al.). The ideas of the concept of tourism as a social development project were substantiated by such scholars as Hunzicker (1957), Minnaert et al. (2009), Higgins-Desbiolles (2006), Griffin et al. (2011), Almeida (2011), Alkier et al. (2017).

An analysis of the social aspects of tourism development as a separate area of scientific research can be seen in the writings of such scholars as A. Holod (2015, 2019), L. Nemets (2009), K. Sehida (2009), L. Fedoryshyna (2019) et al. The works of such scientist as K. Zadorozhna (2016) distinguish the social tourism as a separate direction of the tourism industry and an element of the social policy complex.

However, despite the considerable scientific experience of studying the above mentioned issues, the issue of developing the social doctrine of tourism is still not wellresearched by scientists and economists.

\section{OBJECTIVES}

The purpose of the article is to analyze theoretical and methodological approaches to the definition of the social doctrine of tourism, to distinguish its structure and to outline cultural and educational aspects.

\section{METHODOLOGY}

In order to achieve the study aims, the research is based on a comprehensive review of journal articles, conference papers, books and edited volumes. A structural model of the research object was developed according to the results of elaboration and generalization of existing approaches to the study of social aspects of tourism.

\section{RESULTS}

It should be noted that today the definition of the "social doctrine of tourism" is practically absent in the scientific economic literature. The issues regarding the development of theoretical and methodological approaches to the definition and structure of the said concept, criteria of selection for assessing performance of the establishment of the Social Doctrine of tourism and integrated evaluation of its implementation mechanisms aimed at solving applied regional problems in tourism require special studies. 
In our opinion, the social doctrine of tourism should determine the system of conceptual ideas and views on the strategy and main directions of tourism development in the state during a certain time period, taking into account actual needs (tasks) and peculiarities of the development of its social sphere. The social doctrine of tourism is a very capacious concept that is directly oriented to practical application and the effectiveness of its implementation depends on the coherent work of all system components.

Taking into account all of the above, we can distinguish the structure of the social doctrine of tourism, which is presented in Fig. 1.

As can be seen from the figure, the development of the social doctrine of tourism involves the implementation of specific tasks in each of its nine areas: culture, science, education, information provision, social infrastructure, tourism business, social tourism resources, social security of tourism and social management.

The key issue in the development of the social doctrine of tourism is the educational component, which includes a system of training of personnel for tourism industry - higher and vocational education, as well as institutions for improving the skills of tourism professionals. In modern conditions, tourism is oriented to meet the needs of certain social groups and individuals. In such conditions, the requirements for the intellectual abilities of the personnel of tourism industry, their personal characteristics and the valuable ability to acquire and rationally use knowledge and aspiration for self-development are increased.

In recent years, in professional tourism education, there are processes aimed at improving its quality (integration, diversification, unification), due to increased demand for quality services and the related need for the training of competitive tourism industry professionals who have a number of professionally important knowledge, abilities, skills, personal qualities.

\section{DISCUSSION}

In the general sense, the term "doctrine" (from the Latin doctrina - doctrine) is understood as a doctrine, a scientific or philosophical theory, a political system, a guiding theoretical or political principle, or a normative formula. In the origin of this term, the relationship between Latin docere (teach) and doctor (religious teacher, teacher) is traced in the origin of this term. It is a certain systematic doctrine (philosophical, political and ideological), a related concept, a set of principles.

The doctrine is also defined as a part of science, built in accordance with the thought that has replaced the outdated provisions; the interpretation of controversial scientific issues, especially social and philosophical (Popov 1907; Chudinov 1910).

In the English-language sources, the doctrine is generally interpreted as: 1) the principle or the system of principles, beliefs, especially political or religious, which are taught and adhered to by certain groups or in a specific situation; 2 ) the principle of state policy is outlined, mainly in foreign policy or military affairs.

In a more narrow sense, the doctrine is a set of rules, principles and views from a certain area of philosophy, morals, politics, etc., characteristic of a particular thinker, public figure or school, which is the main program of their action (Komlev 2006). In this sense one can speak about the political, legal, economic, military, social, national doctrine of education development, etc.).

Doctrinalness is a universal law of social management the development and implementation of doctrine in the management process allow in practice to implement the systemic nature of managerial influence in any field of vital activity of society. By general rule, any doctrine is divided into an official, created at the national level or supranational (expert conclusions), and scientific, created at universities and other professorial associations.

The doctrine should determine the content of public administration, form and put into effect the mechanism for its implementation. From these positions of managerial understanding of the direction of state policy, in our opinion, the most meaningful is the interpretation of the doctrine, as a system of values and goals, state and management measures, decisions and actions, formalized by the relevant regulatory legal acts and programs, which are aimed at the implementation of publicly set goals of the social development (Yakunin et al. 2010). In the opinion of the aforementioned authors, the doctrine serves as the source and basis of a specific state policy.

It should be noted that in the special literature, including economic, the study of social aspects of doctrine is poorly researched. Instead, enough attention is given to this problem in cultural and theological literature.

The social doctrine is a kind of global technology that determines the place of the social system in the geopolitical space, highlights priorities in the implementation of the indigenous social interests of a particular nation, contains mechanisms for their implementation (economic, international, cultural and spiritual, environmental, military) and is fundamental to determining the strategic goals of social policy, the definition of social guidelines for reform, the elaboration of any kind of policy of expressing the interests of citizens (Sinitskaia 2015).

Proceeding from this, in shaping the social doctrine of the state, one should distinguish: 1) the main national interests that meet the prospective goals of this country and of all mankind; 2) interests, the satisfaction of which primarily depends on the national security of the country and the possibility of the existence of an independent national state; 3) the main resources that can be used to achieve strategic social goals, improve the quality of life of their citizens (Koveshnikov 2002).

The process of developing the social doctrine of the state should provide a thorough scientific analysis of the social and economic situation within it, an objective assessment of previous experience in all spheres of public life, study of external and internal factors of influence on the course of social processes, analysis, borrowing and adaptation of the leading trends of world development with their subsequent adaptation for the effective social development of specific regions.

Clearly expressed social orientation is a characteristic feature of modern tourism, in connection with which more and more scientists define tourism as a special social sphere of the economy. The substantive essence of this statement most successfully transmits the definition of social tourism, which was developed by such scholars as Lynn Minnaert, Robert Maitland and Graham Miller (2009): "social tourism is tourism with added moral value for both sides of the tourist exchange". 
The social orientation of the modern tourism is manifested through the constant expansion of the directions of its development and the formation of ideological landmarks of the level and quality of life - along with active rest and participation in business, scientific and cultural events, tourist trips are carried out with sporting, wellness, religious, environmental, cultural and cognitive, historical, literary, artistic, gastronomic, medical, educational and other purposes.

Consumption of tourist services as a type of human life also has a pronounced social character - in the process of receiving services is intense cultural communication of a certain number of people (tourists, staff, local population) at certain points of social space. Consumption of tourist services as a sign of social stratification with the growth of tourist flows can acquire negative features, including the presentation of national cultures and ethnic traditions as a specific product, the decline of the level of spiritual culture, the growth of crime, etc.), increases the need for the development and implementation of strategic development measures of the country the sphere of tourism within its borders with the preservation of national culture and identity with the use of any toolkit.

\section{CONCLUSION}

In summary, the conducted research made it possible to substantiate the definition of the concept of "social doctrine of tourism" and to characterize its structure, emphasizing the decisive positions of cultural and educational components.

\section{RECOMMENDATIONS}

Further scientific researches of the social doctrine of tourism should be aimed at the development of the theoretical and methodological foundations of the formation and implementation of social doctrine, the definition of effective methods for researching social processes in the field of tourism, especially cultural and educational, the creation of mechanisms for the implementation of the social doctrine of tourism in order to increase the level of social and economic development of states and regions.

\section{REFERENCES}

1. Alkier R, Milojica V, Roblek V 2017. Challenges of the social innovation in tourism. Tourism in Southern and Eastern Europe, 4: 113.

2. Almeida M 2011. Case study: the development of social tourism in Brazil. Current Issuesin Tourism, 5: 483-489.

3. Aparina NF 2015. Tourism as a sphere for the development of productive enterprises in the region of the resource type. Vestnik Kemerovskogo gosudarstvennogo universiteta, 2(62): 142-146.

4. Asipova ZhM, Aktymbaeva AS 2014. Comparative analysis of the conceptual apparatus of social tourism. Innovation Management and Technology in the Epoch of Globalization: Proceedings of the International Practical Conference: 67-74.

5. Badin AA 2008. Marketing tools for the development of social tourism in Russia. Ekonomicheskiy vestnik Rostovskogo gosudarstvennogo universiteta, 3: 222-225.

6. Holod AP 2015. Social and informational aspects of tourism security. Administratsiia, upravlenie $i$ ikonomika, $8 . \quad$ From <http://ejournal.vfu.bg/bg/pdfs/Socialnie-3.pdf> (Retrieved on 10 June 2019).

7. Holod AP, Fedoryshyna LM 2019. Social problems of organization of international inbound tourism in Ukraine. Sustainable development of the economy, 1(42): 115-121.

8. Hryshkin VO 2001. Socialization of the economy as a reality of modern civilization development. Actual problems of the economy, 10: 31
9. Husliakova OYu 2012. Development of regional targeted programs for the development of the tourism industry. Derzhava ta rehiony, 2(38): 155-158.

10. Dusenko SV 2011. Sociology of tourism: social and cultural aspect. Servis PLUS, 4: 18-26.

11. Griffin K, Stacey J. 2011. Towards a «tourism for all» policy for Ireland: achieving real sustainability in Irish tourism. Current Issues in Tourism. Special Issue: Social tourism: Perspectives and potential, 5: 431-444.

12. Higgins-Desboilles F 2006. More than an «industry»: The forgotten power of tourism as a social force. Tourism Management, 6: 11921208.

13. Hunziker W 1957. Cio che rimarrebbe ancora da dire sul turismo sociale. Revue de tourisme, 2: 52-57.

14. Koveshnikov EM 2009. State and local self-government in Russia: theoretical and legal foundations of interaction. Moscow: Norma.

15. Minnaert L, Maitland R, Miller G 2009. The Value of Social Tourism foundations. Annals of Tourism Research, 2: 316-334

16. Niemets LM, Sehida KYu, Moshtakova NV. 2009. Social and demographic and historical and cultural factors of tourism development. Kultura narodov Prichernomoria, 176: 145-147.

17. Serdobolskaia IO 2003. State regulation of social tourism and ways to improve it in the Russian Federation. Ph. D. Thesis, Published. St. Petersburg: St. Petersburg State University of Economics and Finance. From <https://www.dissercat.com/content/gosudarstvennoeregulirovanie-sotsialnogo-turizma-i-puti-ego-sovershenstvovaniya-vrossiisko/read> (Retrieved on 10 June 2019)

18. Shevchuk LT, Fedoryshyna LM 2015. Migration Acculturation: Problems and Consequences in Ukrainian Society. Visnyk Odeskoho natsionalnoho universytetu. Ekonomika, 6: 192-197.

19. Yakunin VI, Sulakshin SS, Bagdasarian VE 2009. The role of education as a factor in modern economic development. Ekonomika obrazovaniia, 4: 11-25.

20. Zadorozhna KI 2016. Social tourism in the tourism industry: conceptualization and integration. Visnyk Chernivetskoho torhovelnoekonomichnoho instytutu, 2(62): 17-27.

21. Zybarieva OV 2014. Mechanisms of prevention of deviant socialization of the economy of regions. Naukovyi visnyk Bukovynskoho derzhavnoho finansovo-ekonomichnoho universytetu, 26: 36-46.

\section{AUTHORS PROFILE}

Fedoryshyna Larysa,Dr. Sc. (Econ.), Assoc. Prof.,Senior Research Fellow at the Department of Researches of Customs Risks,Scientific and Research Center of Customs Affair of Research Institute of Fiscal Policy of University of State Fiscal Service of Ukraine,Khmelnytskyi, Ukraine,email: larisa.fedorishina@gmail.com,

Felenchak Yuliia,Cand. Sc. (Econ.),Assistant Professor at the Department of sports tourism,Lviv State University of Physical Culture named after Ivan Boberskyi,Lviv, Ukraine, e-mail: yufelenchak@yahoo.com,

Nyanko Vitaliy,Cand. Sc. (Econ.), Assoc. Prof.,Assistant Professor at the Department of Marketing and Commercial Business, Khmelnitsky National University,Khmelnytskyi, Ukraine, e-mail: nvmmarket@gmail.com 